\title{
NYC, Chicago, Los Angeles: Mayoral Speeches as a Source of Information
}

\author{
Clovis Ultramari \\ Urban Management, Pontifical University of Parana, Curitiba, Brazil
}

\section{Email address:}

ultramari@yahoo.com

\section{To cite this article:}

Clovis Ultramari. NYC, Chicago, Los Angeles: Mayoral Speeches as a Source of Information. Urban and Regional Planning.

Vol. 4, No. 3, 2019, pp. 109-114. doi: 10.11648/j.urp.20190403.14

Received: August 7, 2019; Accepted: October 15, 2019; Published: October 23, 2019

\begin{abstract}
This paper is part of a larger research carried by its author on the big scenarios of the contemporary city. It is thus part of a larger effort to understand what the contemporary city is, who its main social agents are and what its main characteristics, problems and potentialities are. This paper presents the results of a specific investigation on the use and potentialities of mayoral inaugural speeches as a tool to understand cities and their contexts. It is based on a previous understanding that these documents are rich in information, both explicit and implicit ones. As a case study three North American cities are taken as examples: New York, Chicago and Los Angeles. Main source of information are: a theoretical review by means of an exploratory investigation and contemporary mayoral speeches available in the internet. Conclusions are limited to the volume of documents selected but indicate the validity to enlarge temporal and geographic scopes. Despite political intentions and hidden interests, speeches confirm to be potential sources of information to understand specific cities, and, what is considered more important, to describe aspects of contemporary urban life in similar socio and economic circumstances. Selection of other cities, of circumscribed geographies, as well as the increase of sources analyzed may reiterate conclusions presented in this paper and lead to other global or regional urban scenarios.
\end{abstract}

Keywords: Political Speeches, Urban Politics, Urban Management

\section{Introduction}

Speeches by political leaders are most commonly written objects of research from the perspective of partisan and ideological alignments. Even in the case of rhetorical pieces delivered by mayors, there is an analytical dearth concerning aspects of what can be conceptualized as "urban management," emphasized in the management of services and basic infrastructure for the population. That same dearth also seems to refer to the lack of analysis in these speeches regarding the role of cities in their larger contexts or even the urban moment. The reiterated historical role of cities [1] thus does not seem to be fully understood in extensive debate known as Discourse Analysis that is observed in areas such as city management.

To fulfill the primary purpose of validating the critical reading of political speeches in order to contextualize urban realities, this article proposes an examination of selected inauguration speeches that are understood to be rhetorical pieces distanced from the electoral process and, therefore, are closer to the material reality of urban management- the main topic of interest to me in this paper.

[...] people in Western democracies, have become frustrated with words as they ask themselves the question 'surely we need actions rather than words?'... However, this would be to ignore the performance aspects of his political communication, and his ability to articulate frustration [2].

A search for similar academic discussions was unsuccessful and, beyond any partisan and ideological discussion, it was found that the mainstream media restricts news to the days following the inauguration, emphasizing the debate on the particular issue at that present time (circumstantial facts determining the outcome of elections).

The study presented in this article was also subjected to the difficulty of accessing mayoral inauguration speeches from different historical series, even when the search was restricted to global or large international cities. In the case of North America, more speeches were available and there was more discussion in the media about their discursive content, even for small and mid-sized cities. Methodologically, there 
were two possible options: work with a long series of speeches from the same cities or with a recent and shorter set from selected cities. As there was better viability for the second alternative, the choice was made to examine mayoral inauguration speeches from the three largest cities in the United States (New York City (New York), Los Angeles, and Chicago) for the last two administrations, with the exception of New York, which also included two inauguration speeches (1994 and 1998) by Mayor Rudolph Giuliani, due to multiple references to theses speeches in subsequent mayoral inauguration documents.

It is assumed that these speeches are not merely oratorical pieces that comply with the formal requirements. Rather the contrary, I assume they are written under a stasis theory strategy; constituting the final piece of an elaborated process meant to determine

where the argument has come to a standstill. [...] what the decision space is in an argument, and [...] where the two sides have agreed that they disagree, [...] a guide to help a rhetor navigate the first canon of rhetoric, inventio $[3, p .8]$.

Through explicitly stated language, the unrevealed, or even through what is said to comply with formalities, they add information that goes beyond a local reality and, if inserted into a larger context, reveal a larger urban world, helping to situate relationships, as well as trends. As a reference for discussions on the spoke and unspoken, that is, strategic resources, it relies on a typical examination of discussions on urban management, but also on the postulates of Charadeau [4] and Maingueneau [5].

The practice of governing, embedded in a particular social reality, also establishes power relationships through the act of language and, permeated by questions of alterity, influence, and regulation, may influence actions. Being aware of the other's point of view and being able to verbalize this observation is the expected political strategy, as Hanna Arendt [6] suggests when considering that the political leader's virtue is concentrated in his/her ability to understand and express the greatest number and greatest possible variety of realities.

The organization of a political action occurs in a discussion space where objectives are defined by representations of power - a political instance - even if they must be controlled by society - a citizen instance [7]. Citizens, through their non-authoritarian will, delegate political power to the elected; paradoxically, as a set of arguments between reason and passion, the elected tend to persuade these citizens to follow their own actions. Unlike the dialectic that proposes a philosophical dialogue, the art of persuasion, of which the speeches analyzed here are examples, comprises the imposition of an opinion - doxa on a group of listeners. In this case, it is a group of diverse constituents and agents of the city. A similar distinction between dialectic and persuasion is observed between speech and discourse: the first takes place in the world of language, while the second takes place at the level of organizing language with psychological and social uses and effects. Mayoral speeches contain indications of an urban management model and a city administration practice as resulting more from the politician's individual view, and less from a democratic consensus or from particular interests showed by a group of interlocutors. Assumptions, recurrently found in discourse analyses, the act of rhetorical communication, ritualized gestures, and utterances allow imaginaries to be constructed, persuasion strategies to be established, and thus influence opinions, obtain supporters, and reduce rejections. There remains, however, room for further debates: on the one hand, possible limitations as an analytical tool, or even simplifications regarding the antipersonification of the subject [4]; and on the other, the potential for application in still-unexplored fields. Limited to an understanding of discourse in its narrowest sense (formal and ritualized, as delivered at mayoral inauguration ceremonies) and aware of its nonlinearity [5], the second investigative possibility was chosen.

In addition to a critical examination, which sought to highlight questions that could explain a larger urban scenario, the selected speeches were examined using the principles proposed by Charaudeau [4], here adapted to urban management issues. The author proposes two large categories: one of credibility - important in demonstrating the administrative legitimacy of the contemporary city manager - and one of identification - important for building an unlimited social affectivity when faced with a dual or fractal city.

This study then evaluates whether the reading of the selected speeches, through the representativeness of their cities in the national or international urban system, beyond their political characteristics and relationships of local interests, may also contribute to the construction of a large urban scenario, sometimes submitting to broader contexts and sometimes imposing facets upon the scenario itself. Although the selected speeches comprise a short historical series, they may also suggest changes and periodizations in the ways people live and manage cities. Studies conducted with a greater number of discursive pieces would broaden the analytical wealth of these findings, perhaps revealing not only temporal changes, but also regional particularities and specificities according to urban typologies.

\section{Identifying Periods}

Political speeches have already been examined using the "historical materialism" of scientific bases, as the works by Althusser; the concept of "discursive formation", as seen in works by Foucault, with the ideas of having assumptions hidden in language; and, more recently, using lexiometric (semantic universe and positioning of the speakers), enunciative (locutional behaviors), and argumentative (logical reasoning) analysis. The analysis in this article, limited to an enunciative and argumentative analysis, sought confirmation of the ability to visualize the city that was and the city that will be, thus suggesting, through discourse analysis, the ability to identify pasts (prior administration evaluations), presents (the determination of the lived city), 
and futures (the new administration that is beginning) for particular urban contexts. Second inaugural speech made by Giuliani in New York, 1998, clarifies this idea:

(...) four years ago, when I stood here and said New York City is the Capital of the World, 'there was doubt. There was fear. And over the last few years, in an exercise of human will and determination, you and I together have changed the direction of the City more than in any four-year period in history. And we should all be proud of that achievement. New York City is now the city Americans most want to live in and visit [8].

Stated boldly, we believe in the possibility of beginning a debate on the urban phenomenon in terms of past, present, and future (at least in the perception of these synthesized moments in the mayor's speech that inaugurates a new administration), and through large periodizations of the recent history of cities. The speech given by Chicago's new mayor, Rahm Emanuel, in 2010 and 2014 [9-10], although clearly intended to value actions of one particular administration over another, suggests a clear periodization of the city's recent history. His words somewhat reproduce that said by his predecessor, Daley, both in ?? inaugural speech [11] and in the following one [12].

A generation ago, people were writing Chicago off as a dying city. They said our downtown was failing, our neighborhoods were unlivable, our schools were the worst in the nation, and our politics had become so divisive we were referred to as Beirut on the Lake [12].

Similarly, in the case of New York, even from a short historical review taken from the selected speeches, a sequence of events is observed as urban inflections [13] capable of determining periods of political and administrative history. In the speeches analyzed, these inflections are included during periods of serious social and economic turmoil prior to Giuliani's administrations [8] and [9], in the period of recovering the city's prominence on a national and global level (during the administrations of that same mayor), and in the period signaling the cities' submission to national or international crises (with the international financial crisis starting in 2008 under Michael Bloomberg's administration) [14-15]. It is obvious that the selected speeches are not enough to make clear conclusions; however, in this case, the literature seems to support the idea of periodizing the city's recent history thusly. Vitale [16], although critical of Giuliani's administration, integrates an analytical recurrence on the years 1970/1980, which reflects a generalized urban crisis for New York.

During the 1980s and early 1990s, the quality of everyday life in New York City underwent dramatic changes, suffering the twin scourges of rising crime and disorder. In 1991, the city's crime rate peaked at its highest level ever, with more than two thousand homicides, and homeless encampments, panhandlers, and drug dealers became a normal part of the urban landscape [8].

With Giuliani, at beginning of his first time (1994), as well as for others who spoke at his inauguration, there was a decision to address the decay-both social and urban-that characterized not only New York, but other major US cities and their once-valued centers more generally; at the time of his second inauguration (1998), there is a possibility for renaissance (also regarded as the neoliberal epopee of the 1990s).

Analyzing the last two mayors of Los Angeles Villaraigosa, 2005-2013 [19] and Garcetti, 2013-2017 [18] makes it equally clear that municipal administration priorities are defined by confronting the international economic crisis, observed since 2008. Additionally, the Mayor Eric Garcetti [18] includes the impact that global actions have on local governments as defining the second decade of the 2000s. More than Villaraigosa, he adopts a monothematic perspective for his inauguration speech, repeatedly warning about the effort required to overcome this crisis. He is vehement about unemployment and a lack of opportunities for businesses, but weak in terms of suggesting concrete initiatives for a scenario that is recognized as persistently negative. That is to say, the prominence of cities in the 1990s, which nurtured international scientific production, now seems to weaken when confronted with global and distant impositions. For Los Angeles, specifically, it is possible to identify a generalized historical period of local governments' limited confrontation with the issues imposed by the international situation.

Believing that the sample of speeches selected may represent a larger scenario of cities and their management proposals between the 1990s and the middle of the second decade of the $2000 \mathrm{~s}$, there is an indication of periods less than a decade accelerating urban processes, which are sometimes more and sometimes less promising. Speeches are used to recognize the urban cycles that are frequently discussed by the seminal literature. It is worthwhile to remember Manuel Castells [19] in The Urban Question, which positions the State with an emphasis on the shaping of the cyclical crises that the urban process is subjected to, or David Harvey [20], in Social Justice and the City, which values the accumulation of income in "circuits of capital." We can then, reiterating what we already know, state that cities are complex, unstable phenomena with an open system; however, we can also recognize that these characteristics tend to be increasingly more profound and are difficult to understand and predict.

\section{The Urban Question}

In the search of great questions that arouse from the speeches selected for the present debate, social aspects stand alone in the public policies since the 1980's. In fact, this is the great urban question that surpasses different ideologies, political parties and perhaps other groups of cities. This is the question that remains always present in the speeches analyzed and, due to references found in them, suggests being present in other similar documents with the same strength. This oratory central piece is thus a transposition of an older one that had pretentiously heralded the construction of a new city or the transformation of existing ones by means 
of technical practices and knowledge, mostly limited to the fields of architecture and engineering. Technicism, so far recurrent and representing the hegemony of the Modernist Movement and of its guidelines expressed in the 1933 Chart of Athens is replaced by a profound interest in social aspects of our urban life, valuing a new set of values flourishes in the defense of social diversity, minorities and vulnerable groups.

However, this replacement maintains one intriguing desire to regard the city as something homogeneous, with no particular interests, or those of minority groups, surpassing the more important concept of a whole urban entity. In the first case, generalization is taken by granted as a necessary basis for implementing universal modernist values, making one single theory able to be adopted in diverse contexts. In the case of cities analyzed here, homogeneity is searched or naïvely believed to exist in order to achieve a massive support for a political idea, project or public policy. Such way of seeing cities demonstrates a unique possibility of putting together the largest number of actors possible and so guaranteeing the support mayors will need in their terms ahead. Being present in all oral pieces analyzed here this intention or strategic approach is equally observed in additional speeches analyzed as marginal references for this research (a list of seven other North American cities, completing the ten biggest cities in the country). This additional reference indicates that not only generalization is common but also suggests it as something new from the 1980 's on.

Although this approach is always present, the way of achieving it varies greatly and may indicate higher or lower subjectivity or even hypocritical gestures. Giuliani, in New York, for example, recognizes the social problem and the responsibility of his administration to deal with them, but he clearly rejects inclusive public policies by means of cash transfers to marginalized groups. "That's not helping them. That's forgetting them. That's not compassion. That's guilt", [8]. Again, in New York, de Blasio [21] considers the social inclusion and prioritizes the reduction of inequities but gives no indication on to implement it. His strategy in this case reiterates something supposed to be always present in the documents analyzed: a clear discrepancy between what is said and what is implemented, between what is rhetoric and is feasible. Lack of precision, instead, also indicated a possible interest in dealing with diversity, complexity and never-ending opposed ideologies. In fact, De Blasio was submitted to a test case of a new left movement that would reach across boundaries of class, race and gender (including sexual identity). [22]

Those earning between \$500,000 and one million dollars a year, for instance, would see their taxes increase by an average of $\$ 973$ a year. That's less than three bucks a day about the cost of a small soy latte at your local Starbucks [21].

The appearance of a new "urban question" in the short historical series is a subject that deserves further investigation. It indicates, once more, that from longer series of selected speeches may flourish or confirm urban inflexions [13] experimented by a specific city or, what would be of fundamental importance, of enlarged national and international scenarios. One more time, such considerations can be enriched by means of enlarging the universe of analysis, both temporal and geographic. As the main reason of this report is to validate the use of inaugural speeches as a methodological tool to satisfy specific investigative interests on urban phenomena, we may so far confirm what was the precondition of the discussion itself.

\section{Conclusion}

Theoretical review in this article - better called a research note - draws our attention to the volume of meanings that may be found in the use of words, syntax and lexis of speeches. In the inaugural speeches made by the mayors of the three selected cities, the recurrent feeling of a mere ceremonial formalism gives place to a rich source of information for research. More than a catalytic element to understand political interests and new or reiterated gatherings in local administrations, such oral documents may inform specific urban realities, as well as an amplified scenario of cities at national and international level. Discussed speeches, historical scope and the quantity of documents establish the limits of any conclusion or generalization; however, more than once, we are tempted to go further these limits.

Individual strategies of one or another mayor and the particularities of this or that city were evident in the discussion. Soares de Souza [23], to whom the way our ideas are written expresses the social context we live in, confirm this analytical potentiality of the speeches. Thus, speeches cannot be taken as an independent expression of those who are entitled to write or to verbalize them. It means that political speeches substantiate as a rich source to reveal: the contemporary city and its historical context, the city and a new urban world imposed by local or global conditions so far not yet largely felt or noticed.

Main purpose of this short article was primarily to discuss the viability and adequacy to use city mayor's inaugural speeches as a material to make urban scenarios visible for scientific research. Density of information found in them respond positively to this question; however, restrictions in terms of their universal availability reduces certain analytical intentions. In the precise case of North American cities, speeches are largely publicized for the big national cities, yet not in specific database concentrating all the information one needs. At the academic level, the use of political speeches as analytical pieces is not a new practice; however, recurrence is observed only in the case of national leaders' and not of municipal administrators'.

In the specific case of the selected cities for this article, final considerations limit themselves to the description of their larger scenarios. By analyzing the historical series, yet short, it is possible to detect a sequence of always present economic crises felt differently by local realities: in fact, speeches either debate a crisis we believe over or confirm a 
new one. The 2008 world financial crisis is announced either as a resistant negative influence on local public administrations or as a fading global externality on cities everyday life.

Another point that may be noticed is that there is a huge, yet fragile or groundless, effort to unite citizens all together in unifying ideas and projects; an impracticable approach that does not take city as fractal phenomenon that more and more rejects homogenizations. "Don't let those who are so fearful of transformation stop the process before it begins. Killing ideas by fear. We don't need to be fearful", said Giuliani to NYC, in 1994 [8]. Mayors, strategically and naively, not only speak in the defense of different and controversial ethnical groups and social classes but also insist in plans and actions to be accepted by a blurred majority of citizens.

Finally, it is important to notice the limitations of local powers in coping international economic or even security crises as confirmed in the case of terrorism. The so-called "protagonism of cities" that is constantly recalled as a local power asset here seems not plausible. Despite being repeatedly mentioned, international crises are considered a phenomenon resulting of distant agents to whom cities merely awkwardly communicate with. To cities is left a series of endeavors that would only be vaguely built. In this case, speeches analyzed here reinforce limitations of cities' and their administrators' protagonism, as recalled by Saskia Sassen [24], to the increasing determination and concrete influence of the international capital.

Other conclusions could be portrayed here, some more other less risky. In order to reinforce the main idea this short exercise allows us to quote Pinto [25] in his statement that democracy is a regime of uncertainties. For the purpose of conclusion, we can rephrase it by saying that the democratic speech is also a speech of uncertainty, able to incorporate new demands, new actors, new phenomena and so reconstruct itself and rejecting its own old truths.

\section{References}

[1] Castells, Manuel e BORJA, Jordi (1996). As Cidades como Atores Politicos. In Novos Estudos Cebrap, n. 45, julho.

[2] Chateris-Black, Jonathan (2018). Analyzing political speeches: rhetoric, discourse and metaphor. Palgrave: London.

[3] Shepard, Bradley. Questions of Stasis in a Post-Truth World. (2019). Thesis submitted to Oregon State University Honors College. Available

<file://C:/Users/ultra/AppData/Local/Packages/Microsoft.Mi crosoftEdge_8wekyb3d8bbwe/TempState/Downloads/Shepar dBradleyW2019\%20(1).pdf> Retrieved: August 31 $1^{\text {st }}, 2019$.

[4] Charaudeau, Patrick (2008). Discurso Político. Sã Paulo: Contexto.

[5] Maingueneau, Dominique (2005). Gênese dos Discursos. Curitiba: Criar Edições.
[6] Arendt, Hannah (2005). The Promise of Politics. New York: Schocken.

[7] Da Costa, Heloiza de Castro (2012). A importância da análise do discurso na compreensão de enunciados. Controvérsia $\begin{array}{lllll}\text { Vol. } & 8, & \mathrm{n}^{\circ} & 2 . & \text { Available }\end{array}$ at: $<$ http://revistas.unisinos.br/index.php/controversia/article/vi ew/5529/2740> Retrieved: Feb. $19^{\text {th }}, 2015$.

[8] Giuliani, Rudolph W. (1998). Second Inaugural Address. New York. 01/01/1998. Available at: $<$ http://www.nyc.gov/html/records/rwg/html/98a/secondina ug.html>. Retrieved: Nov. $3^{\text {rd }}, 2014$

[9] Emanuel, Rahm (2010). Mayor Rahm Emanuel's Inaugural Address. Available at: $<$ http://abclocal.go.com/story?section=news/local\&id $=813$ 3358>. Retrieved: Nov. $1^{\text {st }}, 2014$.

[10] Emanuel, Rahm (2014). Mayor Rahm Emanuel's Inauguration Speech. Available at: $<$ http://www.chicagobusiness.com/section/multimedia0202 ?project=Latest $\% 20$ News\&title $=$ Video $\% 3 \mathrm{~A} \% 20$ Emanuel $\% 27$ s\%20Inaugural\%20Address $>$. Retrieved: Nov. $1^{\text {st }} 2014$

[11] Daley, Richard M. (1989). Mayor Inaugural Address. Available at: $<$ http://www.chipublib.org/mayor-richard-mdaley-inaugural-address-1989/>. Retrieved: Nov. $1^{\text {st }}, 2014$.

[12] Daley, Richard M. (2003). Mayor Richard M. Daley Inaugural Address, 2003. 05/05/2003. Chicago History. Available at: $<$ http://www.chipublib.org/mayor-richard-m-daleyinaugural-address-2003/>. Retrieved: Nov. $2^{\text {nd }}, 2014$

[13] Ultramari, Clovis; Duarte, Fabio (2009). Inflexões Urbanas. Curitiba: Champagnat.

[14] Bloomberg, Michael (2010). Mayor Bloomberg Delivers 2010 Inaugural Address. As He Begins Third Term As 108th Mayor of the City of New York". 01/01/2010. NYC Resources. Available

at: $<$ http://www.nyc.gov/portal/site/nycgov/menuitem.c0935b9 a57bb4ef3daf2f1c701 c789a0/index.jsp?pageID=mayor_press release\&catID $=1194 \&$ doc name $=$ http $\% 3 \mathrm{~A} \% 2 \mathrm{~F} \% 2 \mathrm{Fwww}$.ny c.gov\%2Fhtml\%2Fom\%2Fhtml\%2F2010a\%2Fpr001-

10.html\&cc $=$ unused $1978 \& \mathrm{rc}=1194 \&$ ndi $=1>$. Retrieved: Nov. $10^{\text {th }}, 2014$

[15] Bloomberg, Michael (2006). Inaugural speech. The New York Times. Transcript. 01/01/2006. Available at: $<$ http://www.nytimes.com/2006/01/01/nyregion/01 textbloomberg.html?pagewanted=all\& $\mathrm{r}=0>$. Retrieved: Nov. $3^{\text {rd }}$, 2014

[16] Vitale, Alex S (2008). City of Disorder: How the Quality of Life Campaign Transformed New York Politics. New York and London: New York University Press.

[17] Villaraigosa, Antonio (2005). Much Unsaid in Villaraigosa's Inaugural Talk. Los Angeles Times, 02/07/2005. Available at: $<$ http://articles.latimes.com/2005/jul/02/local/meanalysis2>. Retrieved: Dec. $1^{\text {st }} 2014$.

[18] Garcetti, Eric (2013). Mayor. Inaugural speech. Available at: $<$ https://s3. amazonaws.com/s3.documentcloud.org/docume nts/722888/inaugural-address-eric-garcetti-final-final.pdf $>$. Retrieved Nov. $15^{\text {th }}, 2014$.

[19] Castells, Manuel (1977). The Urban Question: a Marxist approach. London, Edward Arnold. 
[20] Harvey, David (1973). Social Justice and the City, London, Edward Arnold and Baltimore (Md), Johns Hopkins University Press.

[21] Blasio, Bill de (2014). Bill de Blasio's Inauguration Speech. 01/01/2014. The New York Times. Available at: $<$ http://www.nytimes.com/2014/01/02/nyregion/completetext-of-bill-de-blasios-inauguration-speech.html>. Retrieved: nov. $6^{\text {th }} 2014$.

[22] Viteritti, Joseph P. (2017). Bill de Blasio's quest to save the soul of New York. The pragmatist. Oxford University: Oxford.
[23] Soares de Souza, Licia (2009). Interdiscursividades: Bases conceituais para análises críticas do discurso. In Revista Tabuleiro de Letras, n. 02, Sept. Universidade do Estado da Bahia.

[24] Sassen, Saskia (2014). Expulsions: Brutality and Complexity in the Global Economy. Cambridge, MA: Harvard University Press.

[25] Pinto, Céli Regina Jardim (2005). Teorias da Democracia: diferenças e identidades na contemporaneidade. Porto Alegre: Edipucrs. 